\title{
KARAKTERISTIK PRELIMINARY BREAKDOWN PETIR DOWNWARD LEADER SEBELUM SAMBARAN NEGATIF PERTAMA
}

\author{
Zulka Hendri* dan Ariadi Hazmi** \\ *Mahasiswa S2 Teknik Elektro Univertsitas Andalas \\ **Staff Pengajar Teknik Elektro Universitas Andalas
}

\begin{abstract}
Abstrak-Penelitian ini dilakukan terhadap 100 kejadian petir di Kota Padang Sumatera Barat dari bulan Januari sampai Mei 2013. Petir yang dianalisis diawali oleh deretan pulsa preliminary breakdown (PPB) yang terjadi sebelum sambaran negatif pertama dari awan ke tanah. Sinyal petir di rekam dengan memanfaatkan antena medan listrik (fast antenna). Analisis yang dilakukan yaitu PPB-RS separation dan pre-return stroke duration. Analisis PPB-RS separation menghasilkan rata-rata aritmatik 50,62 ms dan rata-rata geometriknya $31,73 \mathrm{~ms}$. Analisis pre-return stroke duration menghasilkan rata-rata aritmatik $54,44 \mathrm{~ms}$ dan rata-rata geometriknya 33,92 ms. Dua tipe deretan pulsa PB yang ditemukan dalam penelitian ini yaitu; (1) deretan pulsa yang didominasi oleh pulsa-pulsa dengan polaritas positif pada setengah siklus pertama, (2) deretan pulsa yang didominasi oleh pulsa-pulsa dengan polaritas negatif pada setengah siklus pertamanya. Deretan pulsa dengan tipe pertama memiliki PPB-RS separation dan prereturn stroke duration yang lebih lama dibandingkan deretan pulsa dengan tipe ke dua. Daerah yang dekat dengan khatulistiwa cenderung memiliki PPB-RS separation dan pre-return stroke duration yang lebih lama dibandingkan daerah yang jauh dari khatulistiwa. Kesimpulan ini diperoleh dengan membandingkan data hasil penelitian ini dengan hasil penelitian yang dilakukan oleh peneliti sebelumnya di beberapa daerah berbeda.
\end{abstract}

Kata Kunci : petir, preliminary breakdown, PPB-RS separation, pre-return stroke duration.

\begin{abstract}
A hundred lightning flash was observed in Padang city, West Sumatera at January until Mei 2013. The lightning that use to analyze is proceeding with preliminary breakdown pulse (PBP) train and followed by first negative return stroke (RS). Fast antenna capacitive was used to record electric field that produced of lightning flash. PBP-RS separation and pre-return stroke duration was used to analyze. Arithmetic and geometric mean of PPB-RS separation is $50,62 \mathrm{~ms}$ and $31,73 \mathrm{~ms}$ respectively. Arithmetic and geometric mean of pre-return stroke duration is $54,44 \mathrm{~ms}$ and $33,92 \mathrm{~ms}$ respectively. We have find two type of preliminary breakdown pulse train are; (1) the pulse train that dominant positive pulse at first half cycle (2) the pulse train that dominant negative pulse at first half cycle. The first type of pulse train have the PPB-RS separation and pre-return stroke duration that longer than the second type. The place that near with equator have PPB-RS separation and pre-return stroke duration that longer than the place far from equator (this conclusion we get from compare the result of our research with the result that produce from the other previous researchers).
\end{abstract}

Keywords : lightning flash, preliminary breakdown, PPB-RS separation, pre-return stroke duration.

\section{PENDAHULUAN}

Proses discharge petir dapat dipelajari dengan observasi terhadap perubahan medan listrik. Hasil observasi perubahan medan listrik memperlihatkan bahwa hampir $90 \%$ dari keseluruhan petir negatif dari awan ke tanah diawali oleh discharge di awan dan mengawali pergerakan ke bawah stepped leader[1].
Preliminary breakdown (breakdown) diasumsi-kan terdiri dari vertical discharge antara pusat muatan negatif dan pusat muatan negatif yang lebih rendah ${ }_{[3] \mid 6]}$ dalam awan petir, dengan durasi 2-10 ms[6]. Deretan pulsa preliminary breakdown kaya dengan informasi yang berhubungan dengan kejadian yang mengawali electric breakdown di awan[2]. 
Perbedaan kondisi georafis daerah akan berakibat pada perbedaan karakteristik deretan pulsa PB yang mengindikasikan perbedaan proses breakdown di awan. Alasan inilah yang mendasari pentingnya dilakukan analisis dan membandingkan karakteristik pulsa PB antara daerah-daerah dengan kondisi georafis yang berbeda [2].

Mengingat masih sedikitnya literatur yang membahas tentang karakteristik preliminary breakdown di daerah yang berdekatan dengan khatulistiwa, maka sangat tepatlah penelitian ini di lakukan di kota Padang Sumatera Barat yang berada di area khatulistiwa.

\section{TINJAUAN PUSTAKA}

Penelitian ini ditujukan untuk mengetahui karakteristik preliminary breakdown petir downward leader yang mengawali sambaran negatif pertama di kota Padang Sumatera Barat.

Deretan pulsa medan listrik yang terjadi beberapa milidetik sebelum sambaran pertama di kenal dengan sebutan deretan pulsa preliminary breakdown (PB)[2], selain itu preliminary breakdown $(\mathrm{PB})$ juga didefenisikan sebagai proses yang terjadi di awan yang melibatkan perubahan konfigurasi medan listrik yang menyebabkan steamer[3-4]. Breakdown awal melibatkan formasi dari satu atau lebih channel di awan. Channel terlihat di perpanjang dengan arah acak dari awan sumber, dan salah satu darinya mengembang terus sehingga terbentuk stepped leader yang menjembatani pelepasan muatan dari awan ke tanah[4]. Pulsa ini biasanya bipolar dengan polaritas pada setengah siklus pertamanya sama dengan pulsa sambaran yang mengikutinya[4-5].

Asumsi dan kriteria yang digunakan untuk mengidentifikasi dan memilih deretan pulsa PB sebelum sambaran negatif pertama berdasarkan konsep dan metodologi yang diperkenalkan oleh Nag dan Rakov (2009)[4] dan juga telah digunakan oleh Baharudin dkk (2012)[2] yaitu: sebuah pulsa dianggap sebagai bagian dari deretan pulsa preliminary breakdown jika dipisahkan dengan jarak yang kurang dari $2 \mathrm{~ms}$ dari pulsa terakhir dan memiliki amplitude puncak ke puncak yang sama atau lebih besar dari dua kali amplitude noise rata-rata.
Analisis yang dilakukan dalam penelitian ini yaitu $P P B-R S$ separation dan pre-return stroke duration. PPB-RS separation didefenisikan sebagai selang waktu antara puncak maksimum medan listrik dalam deretan pulsa $\mathrm{PB}$ dan puncak sambaran[2,3,7] (gambar 1). Pre-return stroke duration didefenisikan sebagai interval waktu antara penemuan pulsa pertama pada deretan pulsa PB dan puncak RS pertama[2] (gambar 2).

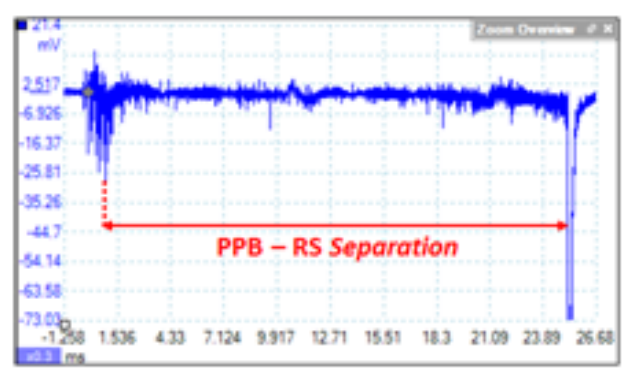

Gambar 1. RS-RS separation.

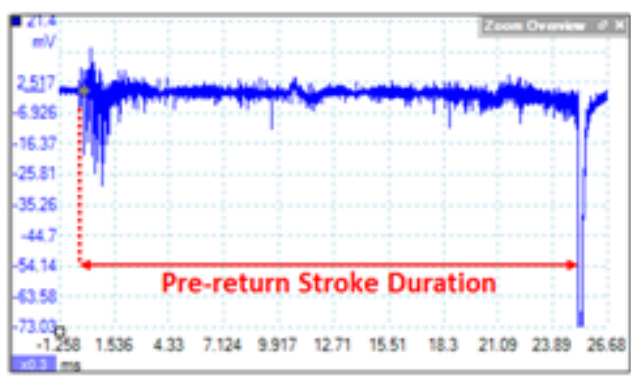

Gambar 2. Pre-return stroke duration.

\section{METODOLOGI}

Penelitian ini dilakukan di Kota Padang Sumatera Barat yang berada di daerah khatulistiwa (lintang: 0 ${ }^{0} 54^{\prime} \mathrm{S}$, Bujur: $100^{\circ} \mathrm{E}$ ), pada ketinggian $303 \mathrm{~m}$ di atas permukaan laut dan berjarak $33 \mathrm{~km}$ dari Bandara Internasional Minang Kabau (BIN). Perekaman terhadap sinyal medan listrik ini dilakukan dari bulan Januari sampai bulan Mei 2013.

Sinyal medan listrik yang dianalisis bersumber dari kejadian petir dengan jaraknya kurang dari $50 \mathrm{~km}$ dari stasiun penerima, ini ditandai dengan bentuk gelombang sabaran pertama yang tidak berosilasi terhadap titik nol. Blog diagram sistem antena medan listrik yang digunakan pada penelitian ini diperlihatkan pada gambar 3 . 


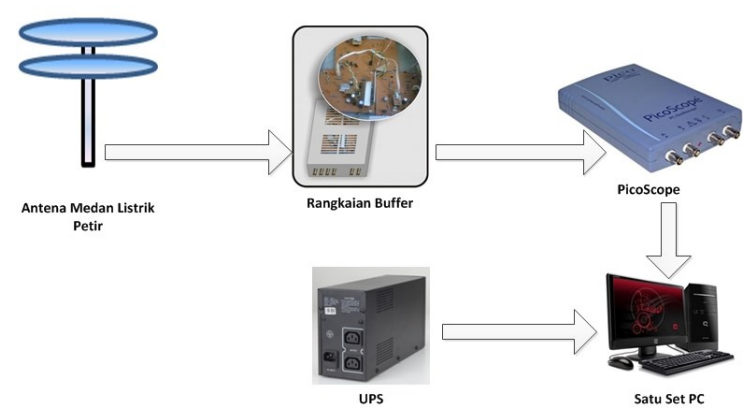

Gambar 3. Blog diagram sistem perekam medan listrik petir.

Instrument yang digunakan dalam penelitian ini memiliki karakteristik yang sama dengan yang diajukan oleh Gomes dkk (1998)[7], walaupun demikian karakteritik pulsa yang di peroleh tidak sepenuhnya sama. Ini disebabkan oleh perbedaan lokasi geografis khusunya lokasi samudra (oceanic location). Peralatan sensor yang digunakan dalam penelitian ini adalah fast anteena capacitive. Sistem perekam ini ditujukan untuk merekam medan listrik yang parallel terhadap bumi (vertikal), dan menghindari terekamnya komponen horizontal, untuk mencapai tujuan ini digunakan antena plat tipis yang memiliki permukaan datar dan dipasang secara vertikal terhadap bumi.Antena ini terdiri dari dua plat tipis yang identic dan terpisah satu sama lain dengan jarak efektif 0,1 $\mathrm{m}$, diameter plat $0,3 \mathrm{~m}$, antena ini berada pada ketinggian efektif $1,5 \mathrm{~m}$ dan $16 \mathrm{~m}$ dari permukaan tanah.

Sepanjang $35 \mathrm{~m}$ kabel coaxial (RG75) digunakan untuk menghubungkan plat antena dengan rangkaian buffer. Kabel coaxial dengan karakteristik yang sama juga digunakan untuk menghubungkan rangkaian buffer dengan 12bit, $20 \mathrm{MHz}$ perekam digital. Sampling rate-nya di set $1 \mathrm{MS} / \mathrm{s}$ dengan lebar total hasil rekamannya $1 \mathrm{~s}$. Setingan trigger perekam digital diseting sedemikian rupa sehingga sinyal dari ke dua polaritas dapat ditangkap dengan baik. Trigger level-nya di seting dari $500 \mathrm{mV}$ sampai $4 \mathrm{~V}$. Perekam digital transien beroperasi $300 \mathrm{~ms}$ sebelum trigger mode.

Sensor ini dirancang untuk dapat mendeteksi perubahan medan kecil yang terjadi sebelum sambaran pertama baik berupa ledakan pulsa PB maupun perubahan medan listrik yang terjadi akibat proses leader yang terjadi berdekatan dengan proses sambaran. Sinyal medan listrik yang di proses pada penelitian ini diikuti oleh sambaran dengan jumlah yang bervariasi dari 1 sampai 11 sambaran.

\section{HASIL DAN PEMBAHASAN}

Analisis terhadap 100 kejadian petir yang telah disebutkan sebelumnya menghasilkan kesimpulan bahwa terdapat dua tipe deretan pulsa preliminary breakdown yang terjadi sebelum sambaran negative pertama dari awan ke tanah di kota Padang Sumatera Barat yaitu:

a. Tipe pertama yaitu deretan pulsa preliminary breakdown yang didominasi oleh pulsa pulsa dengan polaritas positif pada setengah siklus pertamanya (19\%).

b. Tipe ke dua yaitu deretan pulsa preliminary breakdown yang didominasi oleh pulsa-pulsa dengan polaritas negatif pada setengah siklus pertamanya $(81 \%)$.

Deretan pulsa tersebut umumnya bipolar dengan polaritas pada setengah siklus pertamanya umumnya sama dengan sambaran yang mengikutinya ( $81 \%$ data) dan hanya sedikit $(19 \%$ data) yang berbeda dengan polaritas sambaran yang mengikutinya.

\subsection{PPB-RS Separation.}

Hasil analisis PPB-RS separation kejadian petir yang didahului deretan pulsa preliminary breakdown diperlihatkan pada tabel 1. Pada tabel tersebut terlihat bahwa 19 kejadian petir yang didahului oleh deretan pulsa $\mathrm{PB}$ tipe pertama memiliki rata-rata aritmatik $127,26 \mathrm{~ms}$ dan rata-rata geometriknya 109,36 dengan nilai maksimum 243,28 ms dan nilai minimumnya 24,78 ms. Sebanyak 81 kejadian petir yang diawali oleh deretan pulsa PB tipe ke dua memiliki rata-rata aritmatik $32,64 \mathrm{~ms}$ dan ratarata geometriknya $23,74 \mathrm{~ms}$ dengan rentang data 5,7 - 201,52 ms. Sedangkan analisis PPBRS separation gabungan menghasilkan rata-rata aritmatik 50,62 ms dan rata-rata geometriknya $31,73 \mathrm{~ms}$.

Tabel tersebut juga memberikan informasi bahwa PPB-RS separation yang didahului oleh deretan pulsa $\mathrm{PB}$ tipe pertama memiliki ratarata aritmatik yang lebih besar dibandingkan dengan yang didahului oleh deretan pulsa tipe ke dua. Sebaran data PPB-RS separation deretan pulsa $\mathrm{PB}$ tipe pertama diperlihatkan 
pada gambar 4 dan tipe ke dua pada gambar 5 sedangkan gabungan pada gambar 6 .

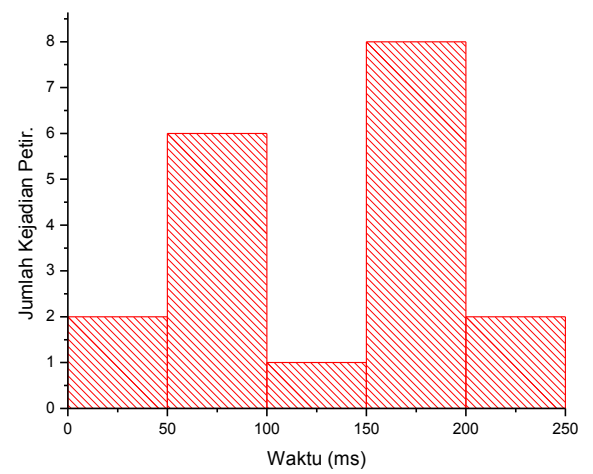

Gambar 4. PPB-RS Separation Deretan Pulsa PB tipe pertama.

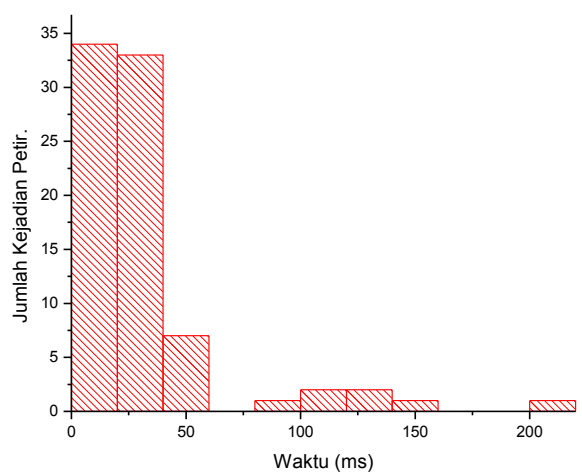

Gambar 5. PPB-RS Separation Deretan Pulsa PB tipe ke dua.

Penelitian PPB-RS separation yang dilakukan oleh peneliti sebelumnya di bererapa daerah dengan posisi lintang berbeda diperlihatkan pada tabel 2. Rangkuman hasil penelitian ini bertujuan untuk melihat kecendrungan PPB-RS separation terhadap posisi lintang suatu daerah. Berdasarkan tabel tersebut dapat disimpulkan bahwa daerah yang lebih dekat dengan khatulistiwa memiliki $P P B$ $R S$ separation dengan rata-rata aritmatik yang lebih besar dibandingkan daerah yang lebih jauh dari khatulistiwa. Ini artinya daerah dengan lebih dekat dengan khatulistiwa memiliki pemisahan pulsa PB dengan sambaran yang lebih besar.

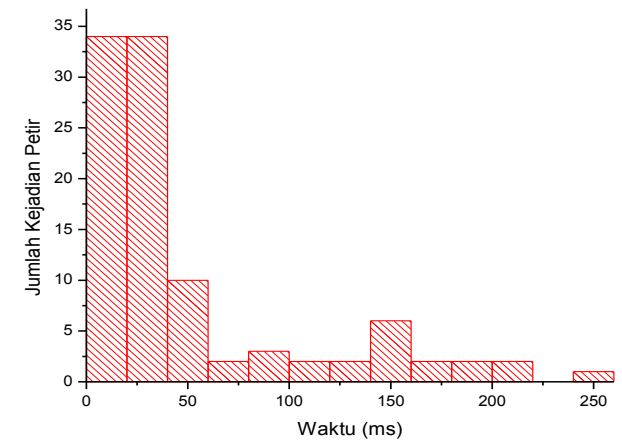

Gambar 6. PPB-RS Separation Gabungan.

\subsection{Pre-return Stroke Duration.}

Analisis pre-return stroke duration kejadian petir yang didahului oleh deretan pulsa PB tipe pertama menghasilkan rata-rata aritmatik $131,25 \mathrm{~ms}$ dan rata-rata geometriknya 114,66 ms dengan nilai maksimal $244,3 \mathrm{~ms}$ dan nilai minimal 37,43 ms, sedangkan Analisis prereturn stroke duration kejadian petir yang didahului oleh deretan pulsa PB tipe ke dua menghasilkan rata-rata aritmatik $36,42 \mathrm{~ms}$ dan rata-rata geometrik $25,49 \mathrm{~ms}$. Analisis prereturn stroke duration gabungan menghasilkan rata-rata aritmatik $54,44 \mathrm{~ms}$ dan rata-rata geometriknya 33,92 ms dengan nilai maksimal $244,3 \mathrm{~ms}$ dan nilai minimal $6,18 \mathrm{~ms}$. Hasil penelitian pre-return stroke duration dirangkum dalam tabel 3.Dengan membandingkan rata-rata aritmatik pre-return stroke duration dari ke dua tipe di atas diperoleh kesimpulan bahwa prereturn stroke duration deretan pulsa $\mathrm{PB}$ tipe pertama memiliki durasi yang lebih lama dibandingkan dengan deretan pulsa PB tipe ke dua (sekitar 3,5 kali tipe ke dua). Sebaran data pre-return stroke duration deretan pulsa PB tipe pertama diperlihatkan pada gambar 7 dan tipe ke dua pada gambar 8 sedangkan gabungan pada gambar 9 . 


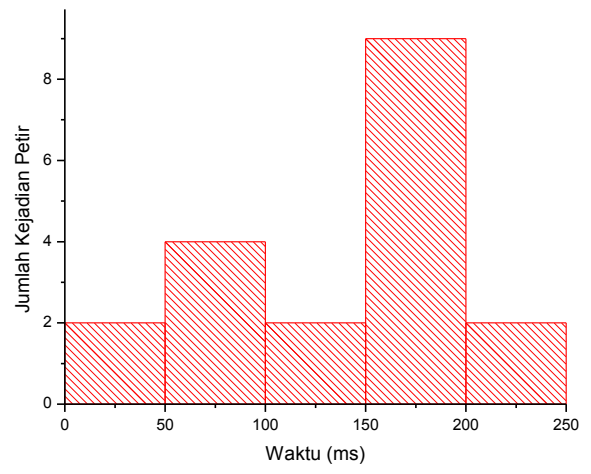

Gambar 7. Pre-return stroke duration deretan pulsa PB tipe pertama.

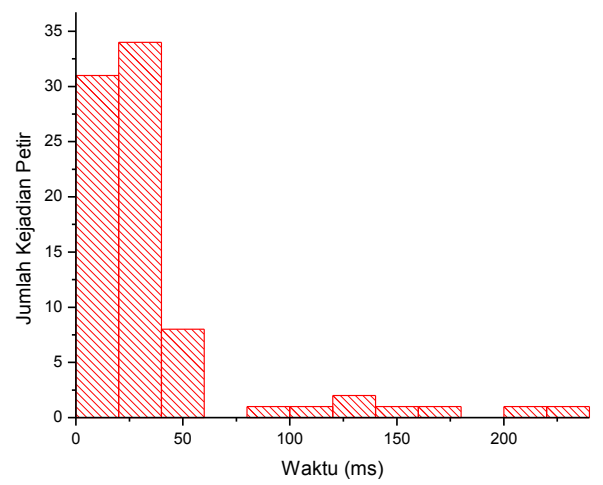

Gambar 8. Pre-return stroke duration deretan pulsa tipe PB tipe ke dua.

Tabel 1. Hasil analisis PPB-RS separation.

\begin{tabular}{|l|c|c|c|c|c|}
\hline \multicolumn{1}{|c|}{ PPB-RS Separation } & $\begin{array}{c}\mathrm{N} \\
(\text { data })\end{array}$ & $\begin{array}{c}\text { Nilai } \\
\text { Max } \\
(\mathrm{ms})\end{array}$ & $\begin{array}{c}\text { Nilai } \\
\text { Min } \\
(\mathrm{ms})\end{array}$ & $\begin{array}{c}\text { Rata-rata } \\
\text { Aritmatik } \\
(\mathrm{ms})\end{array}$ & $\begin{array}{c}\text { Rata-rata } \\
\text { Geometrik } \\
(\mathrm{ms})\end{array}$ \\
\hline $\begin{array}{l}\text { Deretan pulsa yang didominasi oleh } \\
\text { pulsa-pulsa dengan polaritas positif pada } \\
\text { setengah siklus pertama. }\end{array}$ & 19 & 243,28 & 24,78 & 127,26 & 109,36 \\
\hline $\begin{array}{l}\text { Deretan pulsa yang didominasi oleh } \\
\text { pulsa-pulsa dengan polaritas negatif pada } \\
\text { setengah siklus pertama. }\end{array}$ & 81 & 201,52 & 5,70 & 32,64 & 23,74 \\
\hline Kejadian petir di kota Padang & 100 & 243,28 & 5,7 & 50,62 & 31,73 \\
\hline
\end{tabular}

Tabel 2. Hasil penelitian PPB-RS separation dari beberapa peneliti.

\begin{tabular}{|l|l|c|c|c|c|c|c|}
\hline \multicolumn{1}{|c|}{ Penelitian } & Lokasi & Lintang & \multirow{2}{*}{$\begin{array}{c}\text { Jumlah } \\
\end{array}$} & & & \multicolumn{4}{|c|}{ PPB-RS separation (ms) } \\
\cline { 5 - 8 } & & & & Max & Min & $\begin{array}{c}\text { Rat. } \\
\text { Aritm }\end{array}$ & Rat. Geo \\
\hline Penelitian ini. & Padang & $0^{0}$ & 100 & 243,28 & 5,7 & 50,62 & 31,73 \\
\hline Baharudin Z.A & Malaysia & $1^{0}$ & 97 & 227,3 & 8,3 & 57,6 & 47,2 \\
\hline Gomes, dkk & Sri Lanka & $6,9^{0}$ & 9 & 23 & 3,5 & 11,9 & 9,8 \\
\hline Baharudin Z.A & Florida & $27^{0}$ & 100 & 92,5 & 3,3 & 22 & 17,7 \\
\hline Gomes, dkk & Sweden & $59,8^{0}$ & 41 & 70 & 2 & 13,8 & 8,7 \\
\hline Makela, dkk & Finland & $60,4^{0}$ & 193 & 320 & 2 & 18 & 38,5 \\
\hline
\end{tabular}


Tabel 3. Pre-return stroke duration

\begin{tabular}{|l|c|c|c|c|c|}
\hline \multicolumn{1}{|c|}{ Pre-return Stroke Duration } & $\begin{array}{c}\mathrm{N} \\
(\mathrm{data})\end{array}$ & $\begin{array}{c}\text { Nilai } \\
\text { Max } \\
(\mathrm{ms})\end{array}$ & $\begin{array}{c}\text { Nilai } \\
\text { Min } \\
(\mathrm{ms})\end{array}$ & $\begin{array}{c}\text { Rata-rata } \\
\text { Aritmatik } \\
(\mathrm{ms})\end{array}$ & $\begin{array}{c}\text { Rata-rata } \\
\text { Geometrik } \\
(\mathrm{ms})\end{array}$ \\
\hline $\begin{array}{l}\text { Deretan pulsa yang didominasi oleh } \\
\text { pulsa-pulsa dengan polaritas positif pada } \\
\text { setengah siklus pertama. }\end{array}$ & 19 & 244,3 & 37,43 & 131,25 & 114,66 \\
\hline $\begin{array}{l}\text { Deretan pulsa yang didominasi oleh } \\
\text { pulsa-pulsa dengan polaritas negatif } \\
\text { pada setengah siklus pertama }\end{array}$ & 81 & 235,18 & 6,18 & 36,42 & 25,49 \\
\hline $\begin{array}{l}\text { Kejadian petir di kota Padang } \\
\text { gabungan) }\end{array}$ & 100 & 244,3 & 6,18 & 54,44 & 33,92 \\
\hline
\end{tabular}

Tabel 4. Hasil penelitian pre-return stroke duration dari beberapa peneliti

\begin{tabular}{|l|l|c|c|c|c|c|c|}
\hline \multirow{2}{*}{ Penelitian } & Lokasi & Lintang & \multirow{2}{*}{\begin{tabular}{c} 
Jumlah \\
\cline { 5 - 8 }
\end{tabular}} & & & \multicolumn{3}{|c|}{ Pre-return Stroke Duration (ms) } \\
\cline { 5 - 8 } & & & Data & Max & Min & $\begin{array}{c}\text { Rat. } \\
\text { Aritm }\end{array}$ & $\begin{array}{c}\text { Rat. } \\
\text { Geo }\end{array}$ \\
\hline Penelitian ini. & Padang & $0^{0}$ & 100 & 401,14 & 6.57 & 74.53 & 39.01 \\
\hline Baharudin Z.A & Malaysia & $1^{0}$ & 97 & - & - & 62 & 51 \\
\hline Baharudin Z.A & Florida & $27^{0}$ & 100 & - & - & 23 & 19 \\
\hline
\end{tabular}

\section{KESIMPULAN}

Berdasarkan penelitian yang dilakukan dapat disimpulkan bahwa deretan pulsa PB yang didominasi oleh pulsa-pulsa dengan polaritas positif pada setengah siklus pertamanya memiliki PPB-RS separation dan pre-return stroke duration yang lebih lama dibandingkan deretan pulsa dengan polaritas negatif pada setengah siklus pertamanya.

Daerah yang dekat dengan khatulistiwa cenderung memiliki PPB-RS separation dan pre-return stroke duration yang lebih lama dibandingkan daerah yang jauh dari khatulistiwa. Kesimpulan ini diperoleh dengan membandingkan data hasil penelitian ini dengan hasil penelitian yang dilakukan oleh peneliti sebelumnya di beberapa daerah berbeda.

\section{DAFTAR PUSTAKA}

[1] Hazmi, Ariadi dkk. 2013. Characteristics of Electric Field Change Proceding Negative First Return Stroke Produced by Preliminary Breakdown. ICITEE 2013. ISSN: 2088-6579: Yogyakarta.
[2] Baharudin, ZA dkk. 2012. Comparative Study on Preliminary Breakdown Pulse Trains Observed in Johor, Malaysia and Florida, USA. Atmospheric Research . Elsevier.

[3] S Makela, Jakke dkk. 2008. Properties of Preliminary Breakdown Processes in Scandinavian Lightning. Journal of Atmospheric and Solar-Terrestrial Physics. Journal Homepage: www.elsevier.com/locate/jastp. Elsevier.

[4] Nag, Amitabh dan Vladimir A. Rakov. 2009. Electric Field Pulse Trains Occurring Prior to the first Stroke in Negative Cloud-to-Ground Lightning. IEEE Transction on Olectromagnetic Compatiility: IEEE.

[5] Schumann, Carina dkk. 2012. Electric Fields Changes Produced by Positive Cloud-to-Ground Lightning Flashes. International Conference on Grounding and Earthing \& $5^{\text {th }}$ International Conference on Lightning Physics and Effects. Bonito: Brazil.

[6] Clarence, N.D., Malan, D.J., "Preliminary discharge processes in lightning Àashes to ground," Quarterly Journal of the Royal Meteorological Society 83, 161-172, 1957. 
[7] Gomes, Chandima dan Vernon Cooray. 2004. Radiation Field Pulses Associated With the Initiation of Positive Cloud to Ground Lightning Flashes. Journal of Atmospheric and Solar-Terrestrial Physics: Elsevier.

[8] Lin, Y. T., M. A. Uman, J. A. Tiller, R. D. Brantley, W. H. Beasley, E. P. Krider, and C. D. Weidman, "Characterization of lightning return stroke electric and magnetic fields from simultaneous two station measurements," J. Geophys. Res., 84, 6307-6314, doi:10.1029 /JC084iC10p06307, 1979.

\section{Biodata Penulis}

Zulka Hendri, Lahir di Koto Baru pada tahun 1985. Menerima gelar sarjana di Fakultas Teknik Universitas Andalas pada tahun 2011. Sekarang tengah menempuh pendidikan jenjang Megister Teknik Elektro Universitas Andalas Padang. 